Am. J. Nephrol. 1981;1:I-VI

\title{
Contents, Vol. 1, 1981
}

\section{Vol. 1, 1981}

Editor-in-Chief Editorial Board

Shaul G. Massry, Los Angeles, California Zalman S. Agus, Philadelphia, Pennsylvania

Robert J. Anderson, Denver, Colorado

Assistant Editors Jose A.L. Arruda, Chicago, Illinois

David A. Goldstein, Los Angeles, California William M. Bennett, Portland, Oregon

Nachman Brautbar, Los Angeles, California Geoffrey M. Berlyne, Brooklyn, New York

Christopher R. Blagg, Seattle, Washington

Associate Editors Jacques J. Bourgoignie, Miami, Florida i

Neal S. Bricker, Los Angeles, California Barry M. Brenner, Boston, Massachusetts

Eli A. Friedman, Brooklyn, New York Ruth E. Bulger, Houston, Texas

Richard J. Glassock, Torrance, California Vito M. Campese, Los Angeles, California

(Nephrology Consultant Section) Russell W. Chesney, Madison, Wisconsin

Neil A. Kurtzman, Chicago, Illinois Fredric L. Coe, Chicago, Illinois

(Quiz of the Month Section) Ralph A. De Fronzo, New Haven, Connecticut

Solomon Papper, Oklahoma City, Oklahoma Garabed Eknoyan, Houston, Texas

(Progress in Nephrology Section) Murray Epstein, Miami, Florida $\backslash$

Robert W. Schrier, Denver, Colorado Richard N. Fine, Los Angeles, California

Wadi N. Suki, Houston, Texas Jared J. Grantham, Kansas City, Kansas

(Editorials and Reviews Section) Ronald D. Guttmann, Montreal, Canada

Robert L. Vernier, Minneapolis, Minnesota John P. Hayslett, New Haven, Connecticut

(Pediatric Forum Section) Lee W. Henderson, San Diego, California

Robert H. Heptinstall, Baltimore, Maryland

George J. Kaloyanides, Long Island, New York

Norman M. Kaplan, Dallas, Texas

Adrian I. Katz, Chicago, Illinois

Michael Kaye, Montreal, Canada

Carl M. Kjellstrand, Minneapolis, Minnesota

Saulo Klahr, St. Louis, Missouri

Charles R. Kleeman, Los Angeles, California

Juha P. Kokko, Dallas, Texas

Joel D. Kopple, Los Angeles, California

Joseph M. Letteri, East Meadow, New York

Robert G. Luke, Birmingham, Alabama

John F. Maher, Bethesda, Maryland

Manuel Martinez-Maldonado, San Juan, Puerto Rico

Franklin D. McDonald, Detroit, Michigan

Alfred F. Michael, Minneapolis, Minnesota

John S. Najarian, Minneapolis, Minnesota 
Karl D. Nolph, Columbia, Missouri

Donald E. Oken, Richmond, Virginia

Dimitrious G. Oreopoulos, Toronto, Canada

Victor E. Pollak, Cincinnati, Ohio

Jules B. Puschett, Pittsburgh, Pennsylvania :

Floyd C. Rector, San Francisco, California \&gt;

Jay H. Stein, San Antonio, Texas

Philip R. Steinmetz, Iowa City, Iowa

Richard L. Tannen, Ann Arbor, Michigan

Craig C. Tisher, Gainsville, Florida

Curtis B. Wilson, La Jolla, California

Manuscript Consultants

The following consultants have provided valuable assistance in the reviewing of manuscripts during 1980:

Allen I. Arieff, MD Eli Friedman, MD Jacob Lemann, MD Solomon Papper, MD

William Bennett, MD Willa Hsueh, MD Joseph Letteri, MD Victor Pollak, MD

Ruth Bulger, PhD Norman Kaplan, MD John F. Maher, MD Sandra Sabatini, MD

Vito M. Campese, MD Carl Kjellstrand, MD Robert Narins, MD Richard Tannen, MD

Garabed Eknoyan, MD Joel D. Kopple, MD Karl D. Nolph, MD C. Craig Tisher, MD

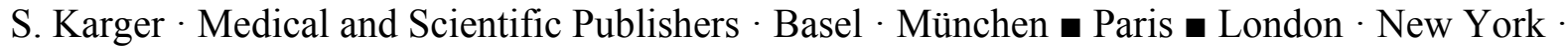
Sydney

Drug Dosage All rights reserved.

The authors and the publisher have exerted every effort to ensure that drug selec- No part of this publication may be translated into other languages, reproduced or

tion and dosage set forth in this text are in accord with current recommendations utilized in any

form or by any means, electronic or mechanical, including photo-

and practice at the time of publication. However, in view of ongoing research. copying, recording, microcopying, or by any information storage and retrieval

changes in government regulations, and the constant flow of information relating system, without permission in writing from the publisher.

to drug therapy and drug reactions, the reader is urged to check the package insert

for each drug for any change in indications and dosage and for added warnings and

precautions. This is particularly important when the recommended agent is a new S. Karger AG,

P.O. Box, $\mathrm{CH}^{\wedge}+009$ Basel (Switzerland)

and/or infrequently employed drug. Printed in Switzerland by Graphische Anstalt Schüler AG, Biel

Contents Vol. 1,1981

No. 1

No. 2

Editorial Review

Continuous Ambulatory Peritoneal Dialysis

Nolph, K.D

1Editorial Review

Contrast Nephropathy

Harkonen, S.; Kjellstrand, C. 
Original Paper

Membranous Nephropathy: Response to Steroids and Immu-

nosuppression

Suki, W.N.; Chavez, A 11

Biochemical Abnormalities of Platelets in Renal Failure

Evidence for Decreased Platelet Serotonin, Adenosine Di-

phosphate and Mg-Dependent Adenosine Triphosphatase

Eknoyan, G.; Brown, C.H 17

Hypotension during Acetate and Bicarbonate Dialysis in Patients with Acute Renal Failure Borges, H.F.; Fryd, D.S.; Rosa, A.A.; Kjellstrand, CM. . 24

Glomerular IgE Deposits in Patients with Lupus Nephritis

Tuma, S.N.; Llach, F.; Sostrin, S.; Dubois, E.L.; Massry,

S.G 31

Incidence of Early Urinary Tract Infections and Relationship to Subsequent Rejection Episodes in

Renal Allograft Recipients

Frei, D.; Guttmann, R.D.; Gorman, P.; Meakins, J.L.;

Morehouse, D.D.; Milne, C; Lowry, R 37

Comparability of Insulin Binding to Erythrocytes and Mono-

cytes from Hemodialysis Patients and Healthy Subjects

Briggs, W. A.; Wielechowski, K.S.; Mahajan,S.K.; McDonald,

F.D 41

Case Reports

Fanconi's Syndrome in Renal Transplantation

Friedman, A.; Chesney, R 45

Antibody to Tamm-Horsfall Protein after Acute Tubular Necrosis

Ooi, B.S.; Weiss, M.A.; Kant, K.S.; Hong, CD.; Pollak,

V.E.; Andriole, V.T 48

Quiz of the Month, Questions 52

Nephrology Consultant

Glomerulonephritis in Systemic Lupus Erythematosus

Glassock, R.J.; Goldstein, D.A.; Finander, P.; Koss, M.;

Kitridou, R.; Border, W.A 53

Original Paper

Crescentic Glomerulonephritis: Immune vs. Nonimmune

Mechanisms

Cohen, A.H.; Border, W.A.; Shankel, E.; Glassock, R.J. . 78 Urinary Calcium Excretion at

Extremes of Sodium Intake in

Normal Man

McCarron, D.A.; Rankin, L.I.; Bennett, W.M.; Krutzik, S.;

McClung, M.R.; Luft, F.C 84

Rhabdomyolysis with and without Acute Renal Failure in

Patients with Phencyclidine Intoxication

Akmal, M.; Valdin, J.R.; McCarron, M.M.; Massry, S.G. 91 Newer Modifications of Peritoneal

Dialysis: Options in the 
Treatment of Patients with Renal Failure

Price, C.G.; Suki, W.N 97

Case Reports

Systemic Hypersensitivity to Allopurinol with Acute Interstitial

Nephritis

Grussendorf, M.; Andrassy, K; Waldherr, R.; Ritz, E. . 105 Recurrent Nephrotic Syndrome with Three Successive Renal

Allografts

Chandra, M.; Lewy, J.E.; Mouradian, J.; Susin, M.; Hoyer,

J.R 110

Quiz of the Month, Questions 115

Progress in Nephrology

Abdominal Computed Tomography: Role in Nephrology

Pederson, J.A.; Papper, S., 116

Nephrology Consultant

Anuria and Acute Renal Failure in a 61 -Year-Old Woman

Glassock, R.J.; Goldstein, D.A.; Romoff, M.S.; Danovitch,

G.M.; Burke, P.R.; Feinstein, D.I 121

Commentary

Isolated Systolic Hypertension: a Fading Myth

Borhani, N.0 129

Quiz of the Month, Answers

68

Quiz of the Month, Answers 131

V

Contents

No. 3-4

Editorial

Success in Management of Renovascular Hypertension: Why

So?

Vaughan, E.D., Jr 133

Original Paper

Alterations of Thyroid Hormone Indices in Acute Renal Failure and in Acute Critical Illness with and without Acute

Renal Failure

Kaptein, E.M.; Levitan, D.; Feinstein, E.I.; Nicoloff, J.T.;

Massry, S.G 138

Noninflammatory Renal Microangiopathy of Systemic Lupus

Erythematosus ('Lupus Vasculitis')

Bhathena, D.B.; Sobel, B.J.; Midgal, S.D 144

Hyperkalemia and Renal Insufficiency: Role of Selective Aldo-

sterone Deficiency and Tubular Unresponsiveness to Aldo-

sterone

Arruda, J.A.L.; Baflle, D.C.; Sehy, J.T.; Roseman, M.K.; 
Baronowski, R.L.; Kurtzman, N.A 160

Case Reports

Primary Necrotizing Arteritis of the Main Renal Artery Pre

senting as Accelerated Renovascular Hypertension

Luger, A.M.; Bauer, J.H.; Neviackas, J.A.; Lee, H.T.; Ni

chols, W.K 168

Absence of Renal Sodium Adaptation in Chronic Renal

Failure

Danovitch, G.M.; Jacobson, E.; Licht, A 173

Systemic Calciphylaxis Revisited

Adrogué, H.J.; Frazier, M.R.; Zeluff, B.; Suki, W.N. ... 177

Medical Art 183

Pediatric Forum

Unique Consequences of Kidney Infections in Infants and Chil

dren: Pathogenesis, Early Recognition, and Prevention of

Scarring

McCurdy, F.A.; Vernier, R.L 184

Quiz of the Month, Questions 198

Nephrology Consultant

Nephrotic Syndrome in a 52-Year-Old Woman with Monoclonal Gammopathy

Glassock, R.J.; Goldstein, D.A.; Levitan, D.; Boylen, T.C.;

Kamil, E.S.; Koss, M.N 199

Review of the Month

Diabetic Nephropathy: Natural Course, Survivorship and

Therapy

McCrary, R.F.; Pitts, T.O.; Puschett, J.B 206

Commentary

Is Membranous Nephropathy Treatable?

Coggins, C.H 219

Medical Art 221

Letter to the Editor

Evolution of Mesangial IgM Nephropathy into Focal Segmental

Glomerulosclerosis

Jennette, J.C 222

Quiz of the Month, Answers 223

Author Index 224

Subject Index 224 